\title{
ПОРЕДБЕНЕ КЛАУЗЕ КАО ДОПУНА ГЛАГОЛИМА НЕПОТПУНОГ ЗНАЧЕЬА У РОМАНУ ЋАКОН БОГОРОДИЧИНЕ ЦРКВЕ ИСИДОРЕ СЕКУЛИЋ ${ }^{1}$
}

\begin{abstract}
САЖЕТАК
У раду се анализирају поредбене клаузе које су допуна глаголима непотпуног значења у роману Бакон Богородичине иркве Исидоре Секулић. У уводном делу рада говоримо нешто више о тим глаголима и њиховим класификацијама у граматикама, док је централни део рада посвећен опису граматичких обележја датих клауза и указано је на њихове поједине семантичке специфичности. Највећи део рада посвећен је поредбеним клаузама уз семикопулативне глаголе изгледати и чинити се. У закључку су дати подаци о заступљености појединачних глагола чија је допуна поредбена клауза.
\end{abstract}

КљУЧНЕ РЕЧИ: српски језик, синтакса, поредбена клауза, фактивност, контрафактивност, везник као што, везник као да, копулативни глаголи, семикопулативни глаголи.

\section{1. Увод}

Предмет истраживања у овом раду јесу клаузе с везником као да у роману Ђакон Богородичине иркве Исидоре Секулић, односно конструкције с речцом као које представљају редуковане клаузе с везником као да или, ређе, клаузе с везником као што, а које допуњују глаголе изгледати, чинити се и глаголе њима сродне по значењу. Сви глаголи чије се допуне анализирају јесу глаголи који не могу да стоје самостално, те су им оне неопходне како би њихово значење било комплетно.

1 Рад представља измењену и дорађену верзију семинарског рада из предмета Синтакса и семантика функиионалних стилова који је рађен под руководством проф. др Јелене Ајџановић. 
Клаузе које допуњују копулативне, модалне, фазне и семикопулативне глаголе одређујемо као предикатске клаузе (Антонић 2018/2019). То су углавном клаузе уведене везником $\partial a$, а у овом раду сусрећемо се с тим да су предикатске клаузе које допуњују копулативне и семикопулативне глаголе уведене везником као $(\partial a)$, који је карактеристичан за поредбене клаузе. Да ли ћемо их одредити као предикатске или поредбене зависи пре свега од тога који аспект анализе нам је у фокусу. ${ }^{2}$ Посматрано с функционалног плана, реч је о предикатским клаузама, док су формално, али и због свог значења, оне поредбене клаузе јер су уведене типичним поредбеним везником и јер садрже три неизоставна елемента сваког поређења: елемент који се пореди, елемент с којим се пореди и њихову заједничку особину, а та особина у случају анализираних примера тиче се сличности спољашњег изгледа два различита ентитета.

Предраг Пипер у Синтакси савременога српског језика: проста реченица наглашава да између непотпуних и осталих глагола не постоји апсолутно одређена граница (Пипер и др. 2005: 324). Већину глагола чије су допуне у овом раду предмет истраживања најпре бисмо сврстали у семикопулативне jep, као и копулативни, не могу самостално да граде предикат, али, с друге стране, нису лишени семантике у оној мери у којој је то случај с копулативним глаголима. Као типични представници семикопулативних глагола најчешће се наводе постати, остати, прогласити, поставити и други глаголи, а њихове допуне Живојин Станојчић и Љубомир Поповић у Граматици српскога језика називају допунским предикативима (Поповић, Станојчић 1992: 228). Исмаил Палић ове глаголе назива глаголима изразито ослабљеног значења не користећи термин семикопулативни глаголи, а њихове допуне обавезним адвербијалним допунама. Разликује обавезне адвербијале за место, начин, количину, узрок, време и намену (Palić 2011: 209). Према његовом тумачењу, глаголе као што су изгледати и чинити се допуњују обавезни адвербијали за начин (нпр. изгледати потиштено).

\footnotetext{
${ }^{2}$ И. Прањковић указује на недостатке постојећих класификација зависних реченица јер сматра да је увек у фокусу један аспект анализе, док се остали занемарују. „Jedinice više sintaksičke razine (ili razina) toliko su raznovrsne da je teško i zamisliti klasifikaciju koja bi bila barem približno iscrpna. Mislim s toga da bi klasifikacije trebalo shvaćati kao svojevrsna polazišta u sintaksičkim istraživanjima" (Pranjković 1986: 64).
} 
Без обзира на то у коју скупину ћемо сврстати све поменуте глаголе, чињеница је да иза њих увек следи допуна и тек с њом преносе заокружену информацију. У овом раду анализирају се те допуне, али оне које су у форми поредбених клауза. Циљ истраживања је издвојити основне обрасце у којима се ове клаузе јављају и утврдити њихове граматичке и семантичке специфичности. За потребе истраживања формиран је корпус од 63 реченице ексцерпиране из романа Ђакон Богородичине цркве Исидоре Секулић, што се показало као довољно за један рад обима попут овог. Реч је, дакле, о књижевноуметничком функционалном стилу, који карактерише изражајност, богатство форме, описи праћени употребом стилских фигура, а често и речи и изрази које нећемо срести у другим функционалним стиловима. Ђакон Богородичине цркве је љубавни роман који потврђује наведене одлике књижевноуметничког стила, а пошто говори о љубави двоје младих, велики број поредбених клауза ${ }^{3}$ не изненађује јер су оне тесно повезане са стилском фигуром поређења.

\section{2. Поредбене клаузе}

Поредбене клаузе јављају се као део зависносложене реченице и њима се најчешће изражава поређење између ситуације означене основном реченицом и ситуације коју означава сама поредбена клауза. Она тада има функцију адвербијалне одредбе. Поређење се може остваривати у пољу квалификације или у пољу квантификације, а постоје три његова степена: поређење по једнакости или еквативност, поређење по неједнакости или диферентивност и поређење по изразитој неједнакости или суперлативност (Антонић 2018/2019). Типични везници за еквативност су како, као што и као да, при чему је разлика између последња два у томе што се везник као што појављује у клаузама које одликује фактивност, а као да у клаузама које одликује контрафактивност. Опозиција фактивност/контрафактивност односи се на то у каквом је односу исказ према стварности. Обележје фактивности одликује клаузе које описују стања која одговарају стварности, док је обележје контрафактивности карактеристично за клаузе чије стање не

\footnotetext{
${ }^{3}$ Мисли се на укупан број поредбених клауза, што подразумева и оне које нису предмет истраживања у раду, односно оне које нису допуна глаголима непотпуног значења. УП. Степанов (2019).
} 
осликава реално стање ствари. Како би ово било јасније, наводимо следеће примере из романа:

Чека је тако као што је она чекала њега тада (75). Гушио се после сваког таквог напрезања као да камење гута [ $\Rightarrow$ а не гута] (51).

Карактеристични везници за диферентивност су него што и него да. У основној реченици налази се придев или прилог у компаративу, а уколико то није случај, онда је обавезно присуство речи друкчије:

Да ли ви верујете да сам ја бољи и друкчији него што сам био (150)? Сцена се завршила друкчије него ито се очекивало (52).

Клаузе са значењем суперлативности многи граматичари не издвајају као посебан тип поредбених клауза. ${ }^{4}$ Ипак, то би требало урадити јер у нашем језику постоје поредбене клаузе које преносе ово значење. Значењем суперлативности истиче се да се радња основне предикације врши у највећем степену, а везници су што уз суперлатив придева или што год с компаративом придева, нпр. Скувала је ручак најбоље ито је умела / Скочио је што год је даље могао / најдаље ито је могао.

Када се поредбена клауза јави уз глагол непотпуног значења, она нема функцију адвербијалне одредбе, већ допуне, јер је њено присуство обавезно. У начелу, све три описане врсте поредбених клауза могу да се јаве као допуна овим глаголима, али примери забележени у корпусу потврђују само оне са значењем еквативности, те ће оне у раду бити детаљније описане.

\footnotetext{
${ }^{4}$ Марина Николић, која се код нас најподробније бавила реченицом с поредбеном клаузом, издваја само еквативне и диферентивне поредбене реченице (Николић 2018: 392). Она чак каже да „највећу разлику (суперлативност) не можемо исказати сложеним реченицама с компаративном клаузом" (Николић 2014: 25). Обележје суперлативности истиче једино код реченица које назива градационе суперлативне реченице (Исто: 185-187).

${ }^{5}$ У роману нису потврђене клаузе овог типа, па је пример конструисан на основу предавања из Синтаксе и семантике сложене реченице код професорке Иване Антонић (2018/2019).
} 


\section{3. Поредбене клаузе као допуна копулативним глаголима}

Копула је глагол јесам, најчешће у енклитичком облику у презенту, а у перфекту је то глагол бити. Допуне копулативних глагола називају се предикативима, а интересантно је да се у граматикама као јединице које могу да врше функцију предикатива обично наводе именичке јединице (именице, именичке синтагме, именичке заменице), придевске јединице (придеви, придевске синтагме, придевске заменице, редни бројеви) и прилози, па се на основу тога разликују именички, придевски и прилошки предикатив, док се клаузе не наводе као јединице које могу заједно с копулативним глаголом да чине предикат (Пипер и др. 2005: 332, Поповић, Станојчић 1992: 216-219). Истина је да се оне ретко јављају у тој улози, али се ипак јављају, и то најчешће у говорном језику, те можемо чути исказе као што су: Tо је да запеваш од среће; Ситуација је да пожелиш да те нема. Ове клаузе углавном замењују неку придевску лексему, али је израз експресивнији када се оне употребе уместо придева. ${ }^{6}$

Анализа корпуса показала је да и поредбена клауза може допуњавати копулативни глагол. Она тада има функцију дела предиката, али истовремено се субјекат, обично просентенцијализатор који се односи на реченични садржај, пореди са садржајем исказаним клаузом:

Кад би изашао на северне двери и долазио ка средини солеје, то је било као кад вечерња мирна светлост клизи по усамљеном путу (21). Други пут опет, тако је као да су и он и све у њему стигли некуда одакле немају жељу да оду (39). Ти ниси осетио, не осећаш ни сад, је ли, да је то сасвим тако било као да си ме слао да живим негде на Јужном полу (64). Зар није то тако као да сам већ једаред умрла (125)?

Први пример илуструје појаву у којој наизглед имамо сложени везник као $\kappa a d,{ }^{7}$ али ради се о томе да се ситуација из главне реченице пореди с другом ситуацијом описаном темпоралном клаузом с везником кад, па се иза овог

\footnotetext{
${ }^{6}$ Овај тип клауза издвојен је, такође, према Антонић (2018/2019).

${ }^{7}$ Марина Николић овај спој третира као комплексни везник који у себи сажима поредбено и временско значење (2018: 397).
} 
споја крије поредбена клауза с везником као што и темпорална клауза са везником $\kappa a \partial^{8}$ :

Кад би изашао на северне двери и долазио ка средини солеје, то је било као што буде онда кад вечерња мирна светлост клизи по усамљеном путу.

Поредбена клауза може да буде део копулативног предиката када се у основној реченици налази семантички субјекат у дативу. То је субјекатски датив носиоца психофизиолошког осећања, а осећање се описује тако што се пореди с садржајем исказаним поредбеном клаузом:

Било јој је као жедној, сувој биљичи, којој је свежа пролећна киша попрскала и умила свега неколико листића на врху (92) $[\rightarrow \ldots$ као што буде жедној, сувој биљии]. Кад доврши певање, сасвим му је тако као да је од Ане домао (94).

\section{4. Поредбене клаузе као допуна семикопулативним глаголима}

\section{1. Поредбене клаузе као допуна семикопулативном глаголу изгледати}

У Речнику српскога језика Матице српске из 2011. године, под одредницом изгле́дати као прво наводи се следеће значење овог глагола: 1. а. имати какав спољашњи облик, изглед. б. (безл.) стварати утисак, чинити ce. ${ }^{9}$ Када је остварено значење 1. а., онда је допуна најчешће неки прилог, евентуално придев: изгледати потиштено/млад. У случају значења 1. б. допуна уз овај глагол је субјекатска клауза: Изгледа да ћемо дуго чекати. Поредбена клауза, такође, може да буде допуна глаголу изгледати с овим

\footnotetext{
8 И. Антонић упућује на то да се у дубинској структури налазе поредбена и темпорална клауза: „U svim slučajevima u pitanju je poredbena klauza čiji predikatski konstituent izostaje u površinskoj realizaciji, a zadržava se prvi član, KAO, složenog poredbenog veznika KAO ŠTO (dakle, drugi član, ŠTO, takođe izostaje u površinskoj realizaciji) koji, stoga, dospeva u kontaktnu poziciju s temporalnim veznikom" (Antonić 2001: 74). Такву темпоралну клаузу иста ауторка у поглављу посвећеној реченици с временском клаузом у Синтакси сложене реченице у савременом српском језику одређује као делимично исказану (редуковану, елидирану) (Антонић 2018: 294).

${ }^{9}$ Остала значења, која се у анализираним примерима нису реализовала, а која Речник наводи, јесу следећа: 2. провиривати из нечега, погле́дати и 3. мотрити кад ће се неко појавити, ишчекивати.
} 
значењем, и када је он употребљен у личном глаголском облику и када је употребљен безлично. У првом случају поредбена клауза може бити уведена везником као што или као да. Када је уведена везником као што, онда је предикат поредбене клаузе, такође, глагол изгледати, а изглед субјекта основне реченице пореди се с изгледом субјекта клаузе. Када је поредбена клауза уведена везником као да, њен предикат најчешће је копулативни, а изглед субјекта основне реченице пореди се с изгледом појма који је саставни део копулативног предиката. ${ }^{10}$

У већини примера овог типа у роману остварена је редукована поредбена клауза с речцом као уместо пуног везника као што или као да. Реконструкцијом дубинске структуре долази се до одговора да ли је редукован везник као што или као да, односно да ли је редукован предикат с глаголом изгледати или с глаголом јесам/бити. ${ }^{11}$

Само у два примера поредбена клауза с везником као да није редукована. Први од та два примера показао је да предикат не мора бити копулативни, већ да може бити и глаголски, али тада су субјекти основне реченице и клаузе исти:

Ђаконово чело је било бело као цвет, Анина коса је изгледала као да ће се сад сва расути (76).

У другом примеру глагол изгледати употребљен је безлично, са значењем које је у Матичином Речнику одређено као 'стварати утисак, чинити се':

\footnotetext{
${ }^{10}$ О редукованим поредбеним клаузама уз глагол изгледати пише И. Антонић у раду посвећеном номинативу, где номинатив уз речцу као одређује као предикатски јер у дубинској структури он чини лексичко језгро копулативног предиката поредбене клаузе (2007: 110-111).

${ }^{11}$ У начелу су увек могуће обе интерпретације, али језички осећај и искуство говоре нам да увек превагне једна од њих тако да смо у раду све редуковане клаузе из корпуса одредили или као оне које у дубинској структури имају везник као што или као оне које у дубинској структури имају везник као да. То можемо да видимо на примеру следеће реченице: Њих двоје изгледали су часом као два стара шћућурена врапияа (86) $[\rightarrow \ldots$ као што изгледају два шћућурена врапияа] / $[\rightarrow \ldots$ као да су два шћућурена врапиа]. Обе интерпретације долазе у обзир, али овакве редуковане клаузе у анализи смо одређивали пре као оне с везником као да, него као оне с везником као штол. У конкретном примеру сматрамо да писац два човека жели да представи као два шћућурена врапца, иако они то нису, и да је стога употребљена поредбена клауза с обележјем контрафактивности.
} 
Уопште је изгледало као да се створени свет враћа натраг у мрак $(121) .{ }^{12}$

Глагол изгледати увек у исказ чији је саставни део уноси компоненту модалности. Модална значења могу бити разноврсна, а оно које преноси глагол изгледати најпре бисмо одредили као епистемичку модалност, која „представља степеновану квалификацију уверености говорног лица у истинитост онога што је означено исказом" (Пипер и др. 2005: 643). Конкретно, код глагола изгледати говорно лице процењује нечији изглед на основу визуелне перцепције с тим што ће, када је поредбена клауза допуна овом глаголу, употребити везник као да када стање не одговара стварности, а везник као што када се изглед упоређује с неким реалним ентитетом.

4.1.1. Редуковане поредбене клаузе са обележјем фактивности као допуна семикопулативном глаголу изгледати

Као што је горе наведено, ове клаузе приликом реконструкције дубинске структуре постају поредбене клаузе с везником као што, а пореди се изглед субјекта основне с изгледом субјекта зависне предикације:

А непосредно пред њим је лежао интересантан костур тичета једног, са кончасто танким ребрима која су изгледала као жище на минијатурном неком инструменту $(68)[\rightarrow \ldots$ као ито изгледају жиие на минијатурном неком инструменту]. И онда је неком дошла идеја да се црква настави пенаста и бела, и да изгледа као ред ивећа на старој рушевини камења $(74)[\rightarrow$... као што изгледа ред ивећа на старој рушевини камења]. Ђакон, доктор теологије и врло учен [...], изгледао је као мали Јова у дедином прслуку $(100)[\rightarrow \ldots$ као ито изгледа мали Јова у дедином прслуку]. Ви ми овде

12 Када поредбене клаузе допуњују лично употребљен глагол, рекли смо да их одређујемо као предикатске уз семикопулативни глагол, али и као поредбене клаузе. Када је тај глагол употребљен безлично, што је случај у овом примеру, онда ту клаузу, такође, можемо третирати двојако: она је субјекатска (што показује тест супституције, јер је може заменити просентенцијална заменица то у номинативу), али ако су нам у фокусу њено значење, форма и везник којим је уведена, одредићемо је као поредбену. Миливој Алановић у Синтакси сложене реченице у савременом српском језику клаузе с везником као да на позицији субјекта назива субјекатским клаузама уз глаголе процене чињеничности (Алановић 2018: 138). 
изгледате као неки изабрани ьуди, као кутак један где има још чисте љубави за иркву и детињег веровања у божју милост (111) $[\rightarrow$... као ито изгледају неки изабрани људи, као што изгледа кутак један где има још чисте љубави].

У прва три примера субјекат поредбене клаузе сам по себи није довољан да би могао постати оно с чиме се нешто пореди - он се мора налазити на неком специфичном месту или у некој специфичној ситуацији. Тако се костур птице пореди са жицама на минијатурном неком инструменту; црква се пореди с редом цвећа на старој рушевини камења; ђакон се пореди с малим Јовом у дедином прслуку.

У последњем примеру, људи с којима се пореди нечији изглед нису само људи, већ изабрани људи, а кутак је кутак један где има још чисте љубави. И они су, дакле, подвргнути детерминацији и то помоћу конгруентног атрибута, односно релативне клаузе. Без детерминације поређење би било сувишно, па и бесмислено.

У следећем примеру поново имамо једно до другог речцу као и везник кад, само што је сада развијена клауза с везником као што допуна глаголу изгледати, а клауза уведена везником кад је темпорална:

(...) и високи њихов прота, коме је и најсвечанији фелон кратак, и изгледа у њему као кад се у малу зевалищу увуче велики неки бумбар (101) $[\rightarrow$... као што изгледа велики неки бумбар кад се у малу зеваличу увуче].

4.1.2. Редуковане поредбене клаузе са обележјем контрафактивности као допуна семикопулативном глаголу изгледати

Ових клауза је више у роману него клауза с обележјем фактивности. Разлог лежи у томе што је реч о љубавном роману односно, како је у уводном делу речено, о дёлу које припада књижевноуметничком функционалном стилу, те се изглед особа и предмета дочарава тако што се пореди с изгледом неког другог ентитета који он не може бити а који је саставни део копулативног предиката поредбене клаузе:

Тога светлог, белог зимског дана, вео његов је изгледао као нека много тужна црнина на снегу (25) $[\rightarrow \ldots$ као да је нека много тужна црнина на снегу]. Сео је на сунцем угрејани камен, који је у 
густој трави изгледао као нека бела простирка $(68)[\rightarrow$... као да је нека бела простирка]. Та је соба изгледала као мала ирква (87) [ $\rightarrow$ ... као да је мала црква]. Очи певача су изгледале као светле тачкице (103) [ $\rightarrow$... као да су светле тачкице]. Богородичина црква је изгледала као игралиште, људи као деца, а деца као рајско извеће $(108)$ [ $\rightarrow$... као да је игралиште, људи као да су деияа, а деца као да cy рајско иявеће]. И такав, сузан и насмејан у исти мах, изгледао је као какав лепи намучени анђео (133) [ $\rightarrow$... као да је какав лепи намучени анђео]. Изгледала је као портре неки (184) [ $\rightarrow$... као да је портре неки].

Да је реч о субјективном опису нечијег изгледа најбоље се види у примерима који у основној реченици осим граматичког садрже и семантички субјекат у дативу носиоца субјективне оцене:

Ани је, напротив, онако витак, млад и зелен, изгледао као стабљика бриљьана која иде да се савије око Христова распећа $(19)[\rightarrow$... као да је стабљика бриљана]. Иринеј му је одједаред изгледао као цезар новог једног племена које тек долази (138) [ $\rightarrow$... као да je цеезар новог једног племена које тек долази].

Ове клаузе најчешће имају копулативни предикат, али ипак он може бити и глаголски и тада су субјекти двеју предикација - основне и зависне идентични:

Обасјати сунцем, са крстовима који су од разбљештених зрака дошли виши, изгледали су ти торњеви као порасли, као на прсте yспети над улицом по којој њихов ђакон хода (37) $[\rightarrow \ldots$ као да су порасли, као да су се на прсте успели над улицом по којој юихов Ђакон хода]. И стога је, у светлости, све изгледало као насилно пробуђено (123) [ $\rightarrow$... као да га је нешто насилно пробудило]. (...) и изгледали су страшни. Као откинути од земље (127) $[\rightarrow \ldots$ као да их је неко откинуо од земље]. ${ }^{13}$

\section{2. Поредбене клаузе као допуна семикопулативном глаголу (у)чинити} ce

13 Приликом трансформације, уместо трпног глаголског придева употребили смо радни како би било очигледније да се ради о глаголском предикату. 
Значење овог глагола чије се допуне у виду поредбених клауза анализирају јесте оно које се у Речнику српскога језика Матице српске наводи као друго: 'остављати какав утисак, изгледати, причињавати се'. ${ }^{14}$ Видимо да се као његов синоним наводи управо глагол изгледати, исто као што се и он наводио као синоним том глаголу. Допуна је најчешће придев у инструменталу, а у савременом језику све чешће уместо инструментала појављује се номинатив: чинити се невештим/невешт. У Речнику се не наводи да овај глагол, баш као и глагол изгледати, може, такође, бити употребљен безлично и тада је његова допуна субјекатска клауза: Чини се да он данас неће доћи. Анализа корпуса показала је и да се поредбена клауза може појавити на месту субјекатске допуне овог глагола.

Поредбене клаузе уз глагол (y)чинити се увек су оне с обележјем контрафактивности. У свим примерима описује се особа, предмет или читава ситуација тако што се пореди с нечим што не може бити.

У безличним реченицама, где поредбена клауза врши функцију субјекта, често је присутан и семантички субјекат у дативу који има семантичку улогу носиоца субјективне оцене:

Сада, међутим, њој се чинило као да је она, Ана, затворена у малу кутију, а кутија с юоме заједно стављена у юену ьубав (55). Понекад ми се чини као да се то душа једног драгог покојника спрема да ме посети (80).

Поједини примери потврђују да семантички субјекат не мора бити присутан на површинском плану, али семантика глагола чинити се таква је да се подразумева да он постоји у дубинској структури исказа, јер када је овај глагол употребљен безлично, мора постојати семантички субјекат с улогом носиоца субјективне оцене:

Са једнога места у женској препрати [joj] се чинило као да тамо, y висини над солејом, престаје оклоп зидова (14) (...). Скоро до пола од угаситог камена, чини се [човеку] као да је иела требало да буде каменита, и као да је остала недовршена зато ито је камен био одвише тврд, и људи се уморили да га раде (74).

\footnotetext{
${ }^{14}$ Прво значење је 'правити се, претварати се, градити се'.
} 
Сви примери из корпуса с лично употребљеним глаголом чинити се садрже редуковану поредбену клаузу коју, када развијемо, добијемо поредбену клаузу с везником као да. Оне имају граматички субјекат у номинативу, а поред њега и семантички у дативу, који на површинском плану недостаје само у првом примеру у следећем блоку:

Узана путања средом храма чинила [joj] се као део неке библијске слике, и представљала стазицу у божје царство $(18)[\rightarrow \ldots$ као да је део неке библијске слике]. Преко солеје је корачао нови ђакон. (...) Свечан и поносит, некима се чини као божја опомена, и улевао им је страх (19) [ $\rightarrow$... као да је божја опомена]. Монах Иринеј (...) чинио се Ани Недићевој као један од оних древних ђакона Пећке nатријариије (21) [ $\rightarrow$... као да је један од оних древних ђакона Пећке патријариије] (...). Монашки завет се младом калуђеру чинио као нека провидна ограда кроз коју се гледа у даљне просторе (43) $[\rightarrow$... као да је нека провидна ограда]. Чак, у једном тренутку, Ана му се учинила као овчщща једна $(73)[\rightarrow \ldots$ као да је овчица једна] (...). Све то доле учинило јој се одједаред као свечана и весела нека народна скупштина (105) [ $\rightarrow$... као да је свечана и весела нека народна скупштина]. Златна одежда ђаконова чинила јој се као сивом прашином посута (107) $[\rightarrow \ldots$ као да је сивом прашином посута].

Ако глагол чинити се из горњих примера употребимо безлично, граматички субјекат основне реченице постаће граматички субјекат поредбене клаузе, која више неће бити саставни део предиката, већ ће преузети функцију субјекта: ${ }^{15}$

\footnotetext{
15 Тестом супституције можемо показати да поредбена клауза има улогу субјекта, и то тако што ћемо је заменити просентенцијализатором то у номинативу, нпр. Понекадми се чини као да се то душа једног драгог покојника спрема да ме посети. $\rightarrow$ Понекад ми се чини то. Предикатску функцију поредбених клауза које су саставни део семикопулативног предиката показујемо тако што семикопулативни глагол заменимо копулативним, а субјективни став искажемо дативом основа/критерија, нпр. Узана путања средом храма чинила [joj] се као део неке библијске слике, и представљала стазииу у божје иарство. $\rightarrow$ Узана путања средом храма била је, према ьеном утиску, као да је део неке библијске слике, и представљала стазииу у божје иарство.
} 
Чинило се као да је узана путања средом храма део неке библијске слике. Некима се чинило као да је нови Ђакон божја опомена. Ани Недићевој се чинило као да је монах Иринеј један од оних древних Ђакона Пећке патријаршије. Младом калуђеру се чинило као да је монашки завет нека провидна ограда кроз коју се гледа у даљне просторе. Учинило му се као да је Ана овчища једна. Учинило јој се као да је све то доле свечана и весела нека народна скупштина. Чинило јој се као да је златна одежда Ђаконова сивом прашином nocyma.

\section{3. Поредбене клаузе као допуна семикопулативном глаголу изгледати} или чинити се

Бројни су примери у роману у којима поредбена клауза с везником као да допуњује глагол који недостаје на површинском плану, а ради се управо о глаголу изгледати односно чинити се у значењу 'стварати утисак', до чега долазимо када реконструишемо дубинску структуру. Када се поредбеном клаузом описује утисак о ситуацији или окружењу, онда је глагол изгледати / чинити се употребљен безлично, а клауза заузима позицију субјекта:

Али мало после, као да се из те тишине почело ослобађати све оно што је малочас прогутала $(128)[\rightarrow$... изгледало је / чинило се као да се из те тишине почело ослобађати све оно што је малочас прогутала]. Уто је дунуо ветар, и тако је љутит ушао у травник, као да сваку поједину сламку хоће засебно да продрмуса $(164)[\rightarrow \ldots$ изгледало је / чинило се као да сваку поједину сламку хоће засебно да продрмуса]. Два уздаха, два занесена погледа, и као да је читав океан стао између овог, юиховог, и оног другог света $(175)[\rightarrow \ldots$ и изгледало је / чинило се као да је читав океан стао између овог, њиховог, и оног другог света]. Не знам шта је ово са мном, тако ништа не схватам и не видим, као да је цео овај свет у кожну лопту ушивен (192) $[\rightarrow \ldots$ изгледа ми / чини ми се као да је цео овај свет $y$ кожну лопту ушивен].

Када се поредбеном клаузом описује изглед неког ентитета, глагол је безлично употребљен уколико је тај ентитет саставни део поредбене клаузе, односно њен граматички субјекат, а уколико је он граматички субјекат основне реченице, тада је глагол употребљен лично. Обе интерпретације су могуће: 
Тај служитељ божји као да је донео неке тајанствене кључе (21) [ $\rightarrow$ Изгледало је / Чинило се као да је тај служитељ божји донео неке тајанствене кључе] / [ $\rightarrow$ Тај служитељ божји изгледао је / чинио се као да је донео неке тајанствене кључе] (...). Стојећи на амвону, с подигнутим ораром и очима, [монах Иринеј] као да је бацао на душе сенку великог и страшног крста (21) [ $\rightarrow$ Изгледало је / Чинило се као да је [монах Иринеј] бацао на душе сенку великог и страшног крста] / [ $\rightarrow$ [Монах Иринеј] је изгледао / се чинио као да је бацао на душе сенку великог и страшног крста] (...). (...) али црква као да није марила за ьегов дубоки поклон толико колико други nут (33) [ $\rightarrow$ (..) али изгледало је / чинило се као да ирква није марила за његов дубоки поклон толико колико други пут] / [ $\rightarrow(\ldots)$ али црква је изгледала / се чинила као да није марила за ьегов дубоки поклон толико колико други пут]. (...) и лице дође тако мајушно и смешно, као да само из себе вири $(49)[\rightarrow(.$.$) изгледа /$ чини се као да [лице] само из себе вири] / [ $\rightarrow(. .$.$) [лице] изгледа / се$ чини као да само из себе вири]. Танка, воштана она рука као да сва грла у себи држи (104) [ $\rightarrow$ Изгледа / Чини се као да танка, воштана она рука сва грла у себи држи] / [ $\rightarrow$ Танка, воштана она рука изгледа / чини се као да сва грла у себи држи] (...). Ви као да хоћете нешто да ми кажете (119) [ $\rightarrow$ Изгледа / Чини се као да Bu хоћете нешто да ми кажете] / [ $\rightarrow$ Ви изгледате / се чините као да хоћете нешто да ми кажете]? Пашковић као да је и сам то хтео што је она хтела (144) [ $\rightarrow$ Изгледало је / чинило се као да је Пашковић и сам то хтео што је она хтела] / [ $\rightarrow$ Пашковић је изгледао / се чинио као да је и сам то хтео што је она хтела]. ${ }^{16}$

Издвајамо још један пример у којем поредбену клаузу можемо тумачити као допуну глаголу изгледати / чинити се, али она може бити и квалификативна одредба за глагол чија се девербативна именица налази у основној реченици:

Ана поче јецати, а маторо псето удари у грчевито, астматично сиктање, као да ће сад душу исплакати (164) $[\rightarrow(. .$.$) изгледало је /$ чинило се као да ће сад душу исплакати] / [ $\rightarrow(\ldots)$ сиктао је као да ће сад дуиу исплакати].

\footnotetext{
${ }^{16}$ Сматрамо да би код интерпретације с лично употребљеним глаголом говорници српског језика пре посегнули за глаголом изгледати него чинити се.
} 


\section{4. Поредбене клаузе као допуна глаголима сродним по значењу глаголима изгледати / чинити се}

Оваквих примера нема много у роману, што не мора да значи да ти глаголи нису продуктивни, већ нису били пишчев одабир у моменту писања. У оба примера која издвајамо из романа наилазимо на исте граматичке специфичности као и у примерима претходно описаним: глагол је употребљен безлично, у основној предикацији налази се семантички субјекат у дативу, док поредбену клаузу одликује обележје контрафактивности, те је везник којим се она уводи везник као да:

Мало после, у најсвечанијем моменту службе, Ани је дошло као да види да је баш он онај који је цркви и Богу најближи и најмилији $(15)[\rightarrow(.$.$) Ани се учинило као да види да је баш он онај који је$ цркви и Богу најближи и најмилији]. Ани се привиде као да гледа Ђакона збиља мртвог (17) [ $\rightarrow$ Ани се учинило као да гледа ђакона збиљь мртвог].

Под одредницом до́ћи у Речнику Матице српске тек код значења које је наведено као 10.б. налазимо оно које је овде употребљено: '(у)чинити се, оставити, остављати неки утисак', а наглашено је и да му је тада допуна придев или поредбена конструкција. Што се тиче глагола привидети се, из Матичиног Речника закључујемо да је он синоним глаголу учинити се јер се под одредницом прѝвидети се наводи само једно значење и то 'показати се у машти, произвести утисак, причинити се, учинити се’.

\section{5. Поредбене клаузе као допуна глаголу осећати се}

Допуна семикопулативном глаголу осећати се, као и глаголу чинити се, најчешће је придев у инструменталу или прилог који је постао од тог придева, нпр. осећати се срећним/срећно, при чему избор допуне није произвољан. Ако је то придев, онда глагол има значење 'бити прожет осећањем нечега', а у случају да је допуњен прилогом, онда он значи 'имати осећање о сопственом стању'. На три места у роману појављује се поредбена клауза с обележјем контрафактивности која је допуна овом глаголу, од чега је два пута редукована: 
Осећао се као прегрит скривене шумске земље, коју је сада први пут обасјала пуна топлота (97) $[\rightarrow$ Осећао се као да је прегрит скривене шумске земље, коју је сада први пут обасјала пуна топлота]. Осећао се као башта: зелен, иветан, свеж, жељан свега, и кише и суниа (97) [ $\rightarrow$ Oсећао се као да је башта: зелен, иветан, свеж, жељан свега, и кише и суниа]. Осећала се као да је много старија од Ђакона (190).

На једном месту изостављена је основна реченица у коју би поредбена клауза била интегрисана, али је јасно да предикат те реченице чини глагол осећати се:

Велика она синоћња непогода утицала је на мене сасвим необично. Као да је олуј и кроз мене прошао (141) [ $\rightarrow$ Oсећам се као да је олуј и кроз мене прошао].

У два случаја у основној реченици налази се декомпоновани предикат с девербативном именицом осећање, која је могла постати и од пунозначног, прелазног глагола осећати и од семикопулативног, медијалног глагола осећати се јер морфема се доследно изостаје када од повратних глагола постане девербативна именица:

Силазећи с амвона, ђакон је имао чудно осећање. Као да му се нешто хладно провлачи испод стихара, пролази кроз одело и груди, и хвата га за срие стиском једним који боли (34) [ $\rightarrow$ Силазећи с амвона, ђакон је осећао као да му се нешто хладно провлачи испод cтихара] / [ $\rightarrow$ Силазећи с амвона, ђакон се осећао као да му се нешто хладно провлачи испод стихара]. Пре тога, она је имала осећање као да је љубав њена мала једна скупоценост, затворена у кутију, и спуштена негде у њено срие или душу (55) [ $\rightarrow$ Пре тога, она је осећала као да је ьубав њена мала једна скупоченост] / [ $\rightarrow$ Пре тога, она се осећала као да је ьубав њена мала једна скупоиеност].

У случају прве интерпретације реч је о допунској клаузи уз прелазни глагол, везник којим је уведена је везник $\partial a$, речца као има функцију да истакне приближност, док се у другом случају ради о поредбеној клаузи са везником као да која је допуна глаголу непотпуног значења. 


\section{5. Закључак}

У овом раду смо имали прилике да видимо да подела зависних реченица може имати недостатке уколико се фокусирамо само на један аспект њихове анализе. У наслову рада посматране клаузе одређене су као поредбене, али је у раду скренута је пажња да су оне истовремено предикатске, односно субјекатске ако имамо у виду функцију коју врше у реченици. У сваком случају оне имају статус допуне, а не додатка, јер је њихово присуство обавезно. Из одабраног извора језичке грађе формиран је корпус од 63 реченице за потребе овог истраживања и готово све су наведене у раду. Од тога је њих 23 (36\%) допуна глаголу изгледати, а он је 22 пута (96\%) употребљен лично и само једном (4\%) безлично. Поредбене клаузе допуњују глагол (y)чинити се 13 пута (21\%), 8 пута (62\%) у личним и 5 пута (38\%) у безличним реченицама. У 13 примера (21\%) из корпуса редукован је глагол из предиката, а реконструкцијом долазимо до закључка да недостаје глагол изгледати или чинити се у значењу у којем они подударају, а то је значење 'стварати утисак'. С овим значењем, у 2 примера (3\%) употребљени су неки други глаголи (доћи и привидети се). Семикопулативни глагол осећати се појавио се у роману 5 пута (8\%) с поредбеном клаузом као допуном, од чега је 2 пута (40\%) овај глагол заступала девербативна именица. Копулативни глагол поредбене клаузе допуниле су 7 пута (11\%) у роману.

У граматикама се ретко спомиње да клаузе могу допуњавати копулативне и семикопулативне глаголе, па и када се спомиње, реч је углавном о клаузама уведеним везником $\partial a$. У анализираним примерима поредбена клауза једини је елемент који директно допуњује глагол. Даљим прикупљањем грађе несумњиво бисмо наишли на још примера с другим глаголима у предикату, који би можда имали другачије граматичке и семантичке специфичности.

\section{ИЗ В О Р}

Секулић, Исидора (1997). Бакон Богородичине цркве. Београд: Плави јахач

ЛИТ Е Р А Т У Р А

Алановић, Миливој (2018). Реченище са допунском клаузом. У: Пипер и др. Синтакса сложене реченице у савременом српском језику. У редакцији 
Предрага Пипера. Нови Сад - Београд: Матица српска - Институт за српски језик САНУ: 91-197.

Антонић, Ивана (2007). Синтакса и семантика номинатива. У: Лингвистичке свеске 6 (ур. В. Ружић, Ј. Грковић-Мејџор). Нови Сад: Одсек за српски језик и лингвистику, Филозофски факултет у Новом Саду: 102-113.

Антонић, Ивана (2018). Реченице с временском клаузом. У: Пипер и др. Синтакса сложене реченице у савременом српском језику. У редакцији Предрага Пипера. Нови Сад - Београд: Матица српска - Институт за српски језик САНУ: 289-363.

Антонић, Ивана (2018/2019). Предавања из Синтаксе и семантике сложене реченице. Пролећни семестар школске 2018/2019. Одсек за српски језик и лингвистику Филозофског факултета Универзитета у Новом Саду.

Николић, Марина (2014). Категорија степена у српском језику: сложена реченица. Београд: Институт за српски језик САНУ.

Николић, Марина (2018). Реченице с поредбеним значењем. У: Пипер и др. Синтакса сложене реченице у савременом српском језику. У редакцији Предрага Пипера. Нови Сад - Београд: Матица српска - Институт за српски језик САНУ: 385-421.

Пипер, Предраг и др. (2005). У: Пипер и др. Синтакса савременога српског језика: проста реченица. У редакцији Милке Ивић. Нови Сад - Београд: Матица српска - Институт за српски језик САНУ.

Пипер, Предраг и др. (2018). Синтакса сложене реченище у савременом српском језику. У: Пипер и др. Синтакса сложене реченице у савременом српском језику. У редакцији Предрага Пипера. Нови Сад - Београд: Матица српска Институт за српски језик САНУ.

Поповић, Љубомир и Живојин Станојчић (1992). Граматика српскога језика: уибеник за I, II, III и IV разред средюе школе. Нови Сад - Београд: Завод за издавање уџбеника - Завод за уџбенике и наставна средства.

РМС (2011). Речник српскога језика. У редакцији Мирослава Николића. Нови Сад: Матица српска.

Степанов, Маја (2019). Поредбене клаузе са значењем еквативности у роману Ђакон Богородичине иркве Исидоре Секулић. Прилози проучавању језика. 50: 149168.

Antonić, Ivana (2001). Vremenska rečenica. Sremski Karlovci, Novi Sad: Izdavačka knjižarnica Zorana Stojanovića.

Palić, Ismail (2011). O glagolima koji vežu obvezatne adverbijalne dopune u bosanskome jeziku. Suvremena lingvistika. LXXII: 201-217. 
Pranjković, Ivo (1986). Zavisne rečenice u hrvatskom ili srpskom jeziku - klasifikacijske nedoumice. Naučni sastanak Slavista u Vukove dane. 15/1: 57-65.

\section{Maja Stepanov}

COMPARATIVE CLAUSES AS VERB COMPLEMENTS WITH INCOMPLETE MEANING IN THE NOVEL ĐAKON BOGORODIČINE CRKVE BY ISIDORA SEKULIĆ

\section{SUMMARY}

In this paper we analyse comparative clauses that complete verbs with incomplete meaning in the novel Đakon Bogorodičine crkve by Isidora Sekulić. In the introduction we speak more about these verbs and their classification in grammar books, whereas the central part of the paper is dedicated to the description of grammatical features of these clauses and their individual semantic specificities are pointed out. The greatest part of the paper is dedicated to comparative clauses besides the semi-copulative verbs izgledati and činiti se. In the conclusion facts are given about the frequency of individual verbs whose complement is a comparative clause.

KEYWORDS: Serbian language, syntax, comparative clause, factivity, counterfactivity, conjunction kao što, conjunction kao da, copulative verbs, semicopulative verbs

$$
\begin{array}{r}
\text { Мср Маја Степанов } \\
\text { Одсек за српски језик и лингвистику } \\
\text { Филозофски факултет, Универзитет у Новом Саду } \\
\text { Србија } \\
\text { majastepanov17@gmail.com }
\end{array}
$$


